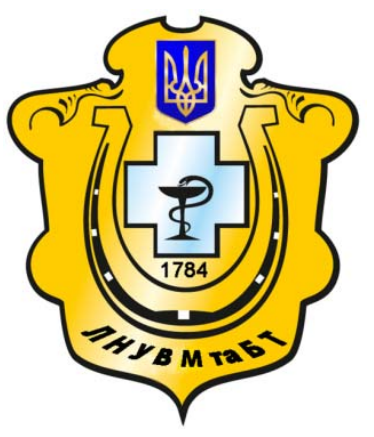

Науковий вісник Львівського національного університету ветеринарної медицини та біотехнологій імені С.3. Гжицького

Scientific Messenger of Lviv National University of Veterinary Medicine and Biotechnologies named after S.Z. Gzhytskyj

doi:10.15421/nvlvet7102

ISSN 2413-5550 print

ISSN 2518-1327 online

$\underline{\text { http://nvlvet.com.ua/ }}$

УДК 619:615.9:616.992-07-08

\title{
Впровадження інформаційно-комунікаційних технологій при викладанні дисципліни «Ветеринарна токсикологія»
}

\author{
Г.В. Бойко, В.Д. Іщенко \\ boiko_gv@nubip.edu.ua, ischenko_vd@nubip.edu.ua \\ Національний університет біоресурсів і природокористування України, \\ вул. Героїв Оборони, 11, м. Київ, 03041, Украӥна
}

\begin{abstract}
Електронне навчання в даний час стає актуальною складовою сучасної освітньої системи, забезпечуючи принципово нові можливості в доступі до освітніх інформачійних ресурсів, в організачії керування освітніми процесами, в актуалізачії освітніх ресурсів і керування ними, в організачї нових освітніх форм з використанням дистанційних форм навчання, значно розиирюючи можливості традиційної освітньої системи.

Висока ефективність освітніх прочесів досягається при спільному використанні різних форм електронного навчання із традиційними формами навчання. Така технологія називається змішаним навчанням (blended-learning).

Метою впровадження електронного навчання є підвищення якості освіти. Завдання ж, розв'язувані безпосередньо за допомогою електронного навчання, можуть бути різні й залежать як від структури самого навчального закладу, так $i$ від етапу розвитку й ряду інших факторів. Використання навчальної-інформаційної системи носить допоміжний характер, $i$ традиційні методи викладання (зокрема, лекиіі) при иььому зберігаються. Однак використання Моодlе дозволяе перемістити рутинні елементи дисиипліни, що не вимагають серйозних консультаиій викладача, у навчальну систему для самостійного освосння студентами, а на лекиіях більше уваги приділяти проблемним питанням дисиипліни.

В статті розглянуто впровадження інформачійно-комунікачійних технологій на кафедрі фармакології та токсикології Національного університету біоресурсів і природокористування України (м. Київ) у викладанні дисципліни «Ветеринарна токсикологія» за допомогою електронного навчального курсу створеного на базі платформи електронного навчання Moоdle і розміщеного на навчально-інформаційному порталі університету.

Ключові слова: інформаційно-комунікачійні технології, електронне навчання навчально-інформаційний портал, ветеринарна токсикологія, Moоdle.
\end{abstract}

\section{Внедрение информационно-коммуникационных технологий в преподавание дисциплины «Ветеринарная токсикология»}

\author{
Г.В. Бойко, В.Д. Іщенко \\ boiko_gv@nubip.edu.ua, ischenko_vd@nubip.edu.ua \\ Наииональный унывверситет биоресурсов и природопользования Украины, \\ ул. Героев Обороны, 11, Киев, 03041, Украина
}

\begin{abstract}
Электронное обучение в настоящее время становится актуальной составляющей современной образовательной системы, обеспечивая приниипиально новые возможности в доступе к образовательным информационным ресурсам, в организаџии управления образовательными процессами, в актуализаџии образовательных ресурсов и управления ими, в организачии новых образовательных форм с использованием дистанционных форм обучения, значительно расширяя возможности традиционной образовательной системы. Высокая эффективность образовательных процессов достигается при совместном использовании различных форм электронного обучения с традиџионными формами обучения. Такая технология называется смешанным обучением (blended-learning).
\end{abstract}

\section{Citation:}

Boiko, G.V., Ischenko, V.D. (2016). Implementation of information and communication technologies at the teaching of «Veterinary toxicology» discipline. Scientific Messenger LNUVMBT named after S.Z. Gzhytskyj, 18, 3(71), 7-10. 
Целью внедрения электронного обучения является повышение качества образования. Задачи же, решаемые непосредственно с помощью электронного обучения, могут быть различны и зависят как от структуры самого учебного заведения, так и от этапа развития и ряда других факторов. Использование учебно-информационной системы носит вспомогательный характер, и традиционные методы преподавания (в частности, лекичи) при этом сохраняются. Однако использование Moоdle позволяет переместить рутинные элементы дисциплины, которые не требуют серьезных консультаций преподавателя, в учебную систему для самостоятельного освоения студентами, а на лекииях больше внимания уделять проблемным вопросам дисииплины.

В статье рассмотрено внедрение информационно-коммуникачионных технологий на кафедре фармакологии и токсикологии Национального университета биоресурсов и природопользования Украины (2. Киев) в преподавании дисциплины «Ветеринарная токсикология» с помощью электронного учебного курса создан на базе платформы электронного обучения Moodle и размещенного на учебно-информачионном портале университета.

Ключевые слова: информационно-коммуникационные технологии, электронное обучение, учебно-информационный портал, ветеринарная токсикология, Moоdle.

\title{
Implementation of information and communication technologies at the teaching of «Veterinary toxicology» discipline
}

\author{
G.V. Boiko, V.D. Ischenko \\ boiko_gv@nubip.edu.ua, ischenko_vd@nubip.edu.ua \\ National University of Life and Enviromental Sciences of Ukrain, \\ Heroyiv Oborony Str., 11, Kyiv, 03041, Ukraine
}

E-learning now becomes an actual part of the modern education system, provides a new opportunity in access to educational information resources, in the management of educational processes, in actualization of educational resources and management them, in the organizing of education new forms by using of distance learning, greatly enlarging possibilities for the traditional educational system. High efficiency of educational processes is achieved by collaborative used of e-learning different forms with traditional learning forms. This technology is called blended learning (blended-learning).

The purpose of implementation the e-learning is to enhance the quality of education. The tasks to be solving directly by using the e-learning can be different and depend on the structure of educational institution and stage of development and other factors.

Using of educational and information system has auxiliary character, and traditional teaching methods (including lectures) in this case saved. However, use of Moodle enables to move routine elements of discipline, which do not require serious consultations of teacher, in the educational system for individually study by students, and at lectures to focus more on problem issues of discipline.

The article deals with the implementation of information and communication technologies in the Department of pharmacology and toxicology National University of Life and Environmental Sciences of Ukraine (Kyiv) at the teaching of "Veterinary toxicology" discipline by using the e-learning course created on the e-learning platform the Moodle and placed on the educational and information portal of the university.

Key words: information and communication technologies, e-learning, educational and information portal, veterinary toxicology, Moodle.

\section{Вступ}

В останній час студенти отримали можливість вільного доступу до мережевих комп'ютерних технологій, що природно призвело до необхідності впровадження цих засобів у навчальний процес.

Для впровадження дистанційної освіти використовують так звані віртуальні навчальні середовища. Найпоширенішою 3 некомерційних систем $є$ Moodle (модульне об'єктно-орієнтоване динамічне навчальне середовище) - система керування навчанням, орієнтована насамперед на організацію взаємодії між викладачем і студентами (Okovyta, 2016; Chastakov, 2016).

Завдяки концепції відкритого програмного забезпечення, що сповідують розробники системи, особливостям технологічної платформи і своїм функціональним можливостям Moodle набуває все більшого поширення в світовому інформаційному освітньому просторі.

Система Moodle надає можливість організувати повноцінний навчальний процес, включаючи засоби навчання, систему контролю й оцінювання навчальної діяльності студентів, а також інші необхідні складові системи електронного навчання (Okovyta, 2016; Chastakov, 2016).

Мета дослідження - показати можливості інформаційно-комунікаційних технологій при викладанні дисципліни «Ветеринарна токсикологія» за допомогою платформи Moodle.

\section{Матеріал і методи досліджень}

Moodle (від англ. Modular Object-Oriented Dynamic Learning Environment - Модульне об'єктноорієнтоване динамічне навчальне середовище; http://moodle.org/) - вільна система управління навчанням (LMS), що розповсюджується за ліцензією GNU GPL. Платформа Moodle написана на PHP 3 використанням SQL-бази даних. Система дистанційного навчання Moodle може працювати з об'єктами SCO та відповідає стандарту SCORM (Kukharenko, 2007).

\section{Результати та їх обговорення}

Платформа Moodle має найширший набір можливостей для повноцінної реалізації процесу навчання в 
електронному середовищі, серед яких - різні опції формування й подання навчального матеріалу, перевірки знань і контролю успішності, спілкування й організації студентів. При цьому всі основні опції системи Moodle розроблялися з орієнтацією на активне залучення студентів у процес формування знань та ïх взаємодія між собою. Moodle $\epsilon$ інтуїтивною та досить простою у використанні платформою, вона дозволяє викладачам реалізувати креативні проекти різного рівня складності.

На кафедрі фармакології та токсикології Національного університету біоресурсів і природокористування України (м. Київ) у викладанні дисципліни «Ветеринарна токсикологія» активно використовується електронний курс створений на базі платформи електронного навчання Moodle i розміщений на навчально-інформаційному порталі НУБіП України

У навчанні студентів із застосуванням даного електронного курсу активно використовуються ефективні методи традиційного навчання в комбінації 3 технологіями електронного навчання.

Мета електронного курсу - забезпечити підвищення ефективності навчального процесу студентів по дисципліні «Ветеринарна токсикологія», за допомогою комбінації традиційного й електронного навчання. Електронний курс «Ветеринарна токсикологія» дозволяє більш ефективно організувати процес навчання, збільшити обсяг навчального матеріалу по даній дисципліні, дає можливість кожному студентові самостійно розбирати теоретичний матеріал і готуватися до лабораторно-практичних занять.

Структура електронного курсу «Ветеринарна токсикологія» базується на блочно-модульному принципі побудови і містить у собі наступні блоки:

- методичні матеріали (робоча програма, методичні вказівки);

- навчальні матеріали (лекції, лабораторні та самостійні роботи);

- контролюючі матеріали (тести до модулів, підсумкова атестація;

- додаткові матеріали (підручники,посібники, інтернет-ресурси, глосарій);

- комунікації (форум, розсилка, обмін повідомленнями).

Усі ці види й форми організації навчання досить дієво й без особливих труднощів реалізуються, якщо використовувати методи традиційного навчання в комбінації 3 технологіями електронного навчання Moodle.

Дослідження різних підходів до проведення лекцій за допомогою технологій електронного навчання (так званих «електронних лекцій») показало, що їх потрібно подавати у вигляді як мультимедійних презентаційний так і текстових варіантів, бажано $з$ перекладом на англійську мову. Це дозволяє подати не тільки власне текст лекції, але й додаткові матеріали - витримки 3 наукових статей і навчальних посібників, посилання на глосарій та інші джерела.

Лекційний матеріал курсу «Ветеринарна токсикологія» представлений за допомогою ресурсу «Вебсторінка», який надає можливість додавання гіпертексту у форматі HTML. Для створення веб-сторінок використовується спеціальний вбудований редактор, досить зручний у роботі. Даний вид ресурсу $є$ найбільш зручним для розміщення навчального контенту. У студента завжди $є$ можливість багаторазового звертання до незрозумілих при читанні місць, чергування читання 3 обмірковуванням, аналізом. Крім того, у тексті легше побачити загальну структуру змісту. Питання, що задаються студентами після з'ясування змісту текстового матеріалу, як правило, більш глибокі по постановці, принципові, по суті, змістовні за формою, оскільки виникають у результату серйозного пророблення матеріалу і його осмисленні.

Глосарій (словник) дозволяє організувати роботу 3 термінами, при цьому словникові статті можуть створювати не тільки викладачі, але й студенти. У курсі «Ветеринарна токсикологія» реалізована можливість автоматичного створення посилань. Терміни, занесені в глосарій, підкреслюються у всіх матеріалах курсу і $є$ гіперпосиланнями на відповідні статті глосарія.

Лабораторні роботи дозволяють на підставі теоретичних відомостей освоїти різні лабораторні методи. Структура лабораторної роботи представлена у вигляді модуля платформи Moodle: назва й ціль роботи, короткі теоретичні відомості, тексти методик визначення отруйних речовин.

Самостійна робота студентів $є$ невід'ємною частиною навчального процесу в підготовці кваліфікованих лікарів ветеринарної медицини. Особливістю Moodle, що полегшує самостійну роботу студентів, є можливість надання йому різноманітних ресурсів, пов'язаних 3 досліджуваною темою: електронних підручників і посібників, презентацій, інтернет-посилань.

Модульний контроль, який містить тести на перевірку засвоєння знань студентом. Здебільшого, перед контрольним тестом за модуль викладач пропонує перелік питань, які виносяться на модуль, та тренувальний тест $з$ самоперевіркою, за допомогою якого студент адаптується до проходження тесту в електронному вигляді. Створюючи тест, технічно можна встановити час на проходження тесту, порядок питань та відповідей.

Така структура електронного навчального курсу «Ветеринарна токсикологія», створеного у середовищі Moodle дає змогу викладачу використати його не тільки під час самостійної роботи студента, але й під час аудиторних занять. Викладач має можливість вчасно впливати на навчальну діяльність студентів, коректувати проблеми у навчанні, а найголовніше розвивати у студентів розуміння й потребу у систематичній самостійній роботі.

\section{Висновки}

Система Moodle допомагає досить ефективно організувати навчальний процес викладання дисципліни «Ветеринарна токсикологія» і дає змогу стимулювати активність студентів у ході навчання й поліпшити засвоєння ними навчальної інформації. Використання електронного курсу «Ветеринарна токсикологія», створеного в Moodle, дозволяє суттєво інтенсифікувати й диференціювати процес навчання, проводити 
підготовку лікарів ветеринарної медицини на новому якісному рівні.

\section{Бібліографічні посилання}

Moodle.org: open-source community-based tools for learning // URL: http://moodle.org/.

Okovyta, T.O. (2016). Systema dystantsiinoho navchannia Moodle [Elektronnyi resurs]. - Rezhym dostupu: http://informatika.udpu.org.ua/?page_id=1325. (in Ukrainian).
Chastakov, A.V. (2016). Metodychni rekomendatsii shchodo pochatku roboty $\mathrm{u}$ systemi dystantsiinoho navchannia Moodle: [metodychni rekomendatsii]. Kirovohrad: KZ «KOIPPO imeni Vasylia Sukhomlynskoho» (in Ukrainian).

Kukharenko, V.M. (2007). Dystantsiine navchannia. Entsyklopedychne vydannia: [navchalnometodychnyi posibnyk]. K.: TOV Redaktsiia «Kompiuter» (in Ukrainian).

Стаття надійшла до редакиії 28.09.2016 